\title{
A CENTURY OLD AND STILL VISIONARY: FAYOL'S INNOVATIVE THEORY OF MANAGEMENT ${ }^{1}$
}

Accepted Feb 2018- European Management Review

\begin{abstract}
Armand Hatchuel, Professor, CGS - i3 UMR CNRS 9217, Mines ParisTech, PSL Research University, 60 boulevard Saint Michel, 75006 Paris, France

Blanche Segrestin, Professor, CGS - i3 UMR CNRS 9217, Mines ParisTech, PSL Research University, 60 boulevard Saint Michel, 75006 Paris, France
\end{abstract}

\begin{abstract}
Based on historical data and a seminal text never translated into English, we present an original interpretation of Henri Fayol's (1841-1925) administrative theory. This interpretation, which is consistent with the comments that Fayol later presented about his "General and Industrial Administration" treatise, brings out his pioneering contribution to management studies. Fayol made the "unknown" introduced by science into industry the central tenet of modern administration. He foreshadowed major aspects of today's innovation management. More fundamentally, Fayol laid new foundations for the field of management sciences. He drew from the political and philosophical works of the Enlightenment to develop a series of original concepts (in French: prévoyance, perfectionnement, programme, inconnu, corps social) that were difficult to interpret and to translate. We maintain that Fayol's administrative science is a theory of a "creative/political" rationality that still, today, offers better theoretical and explanatory support for management science than economic and bureaucratic theory.
\end{abstract}

\section{KEYWORDS}

Fayol, administrative theory, organization theory, management history, innovation management

\footnotetext{
${ }^{1}$ This research was supported by the Chair at Mines ParisTech "Theory of the Firm. Models of Governance and Collective Creation". We are also grateful to Ellen O'Connor for her comments and precious advice.
} 


\section{A CENTURY OLD, AND STILL VISIONARY: FAYOL'S INNOVATIVE THEORY OF MANAGEMENT}

\section{INTRODUCTION}

Based on historical data and a seminal text that has never been translated in English, we present an original interpretation of Henri Fayol's (1841-1925) administrative theory. This interpretation brings out the pioneering nature of his contribution to management studies. Advancing a symbiotic relationship with science, Fayol conceptualized the company (or any modern organization) as a new and specific form of collective value creation and administration as the capacity to prepare the organization to cope with the "unknown" generated by the close collaboration with science.

Finding no theoretical support for these ideas in the conventional administrative or economic theory of his time, Fayol drew from the political and philosophical language of the Enlightenment to develop a series of original, but sophisticated, concepts (in French: prévoyance [foresight], perfectionnement [advancement], programme [program], inconnu [unknown], corps social [corporate body]). The purpose of the administration is, in Fayol's view, to pursue the highest standards of scientific discovery and industrial productivity, while securing the support of the organization and building social cohesion.

Fayol laid the foundations for a new administrative science: this science was not limited to the application of scientific methods to existing administrative processes but very early addressed the organizational challenges of a dynamic, science-driven world. In this way, Fayol not only paved the way for today's innovation management but he also interpreted management theory as an original theory of a "creative/political" rationality, independent of both bureaucracy theory and economics.

\section{From the old to the new Fayol}

In 1916, Fayol published Administration Générale et Industrielle [General and Industrial Administration], hereafter referred to as the GIA. The text was translated into English by Coubrough (Fayol, 1930) and by Storrs (Fayol, 1949) and became a standard reference in management handbooks. The GIA earned Fayol recognition as a pioneer of administrative science, usually interpreted as the application of scientific rationality to administrative processes (Gulick, 1937; Gulick and Urwick, 1937; Urwick, 1937). Fayol became the victim of his own success, however, when the list of his administrative principles extracted from GIA was shrunk into well-worn acronyms, such as POSDCORB (in Coubrough's translation: Planning, Organization, Staffing, Directing, Coordinating, Reporting, Budgeting). This oversimplification led noted scholars to attack Fayol for being banal (Mintzberg, 1975; Simon, 1946).

But recently, a number of scholars have extensively studied Fayol (Peaucelle, 2003a, b; Sasaki, 1995; Reid 1995a, 1995b; Wren, 1992; Wren, 1995, 2001, 2003; Wren, Bedeian and Breeze, 2002, Breeze and Bedeian 1988); the principles of management have been reappraised in light of a detailed account of his career as a manager (Peaucelle and Guthrie, 2015); and the interpretation of his theory has been enriched in several ways. First, many authors acknowledge both the superficial understanding of Fayol and the enduring value of his principles (Chambers 1974; Carrol and Gillen 1987 ; Cohen, 2003; Fells, 2000; Lamond 2004 ; Parker and Ritson, 2005; Pryor and Taneja, 2010). Most notably, they recognize that Fayol anticipated contemporary ideas and practices, such as contingency-based planning, employee involvement, 
and knowledge management (Parker and Ritson, 2005). Yoo et al. interpret the GIA as a guide for implementing Porter's strategy (Yoo, Lemak and Choi, 2006).

Since the dissemination of Fayol's work in English, authors have warned about translation issues. In his foreword to the Storrs translation (Fayol, 1949), Urwick already complained about the translation of administration as "management," which would narrow the scope of Fayol's theory to the realm of industrial management (Urwick, 1949). Brodie (1962) later extended this criticism to other translations of key words in the GIA, such as prévoyance, whose translation as "planning" is constantly discussed (Parker and Ritson, 2005). However, these translation problems were never interpreted as a sign of the sophistication of Fayol's thought; neither have they led to a significantly different reading of Fayol.

\section{Fayol and the purpose of GIA: the forgotten statements of La Notice (1918)}

Peaucelle (2003) was the first to remark that the guiding thread of Fayol's life and works was "its interest for scientific research" (Peaucelle, 2003: 24). Fayol led pioneering initiatives in the natural sciences, including mining, geology and metallurgy, that were linked to his managerial duties (Peaucelle and Guthrie, 2015). In particular, he supported the work of Charles-Edouard Guillaume, who won the Nobel Prize for Physics in 1920, and contributed significantly to Fayol's success in the development of innovative industrial steels at the Imphy plant (Cahn, 2005). In spite of his outstanding commitment and support to science that we describe in the next section of this paper, most scholars separated Fayol's scientific achievements from his administrative theory and practice (Urwick, 1949).

Yet, Fayol himself claimed his administrative theory aimed at fostering scientific and technological breakthroughs:

To be sure to achieve collaboration between science and industry, scholars must be involved systematically. The company's chief executive must therefore know how to prepare and coordinate the work of very different characters; he or she must be a good administrator. Combining the efforts of scholars and practitioners is not a chief executive's easiest task. There are many obstacles to overcome: we showed this in our book on General and Industrial Administration. However, at the same time, we emphasized the crucial need for the chief executive to organize and achieve collaboration between science and business. This idea, which is filled with promise and is now gaining currency, has been important to me for a long time. On this point, our company set the example [our translation from (Fayol 1918: 20)].

This statement comes from Fayol's Notice sur les travaux scientifiques et techniques de M. H. Fayol, 1918 (Notice on the scientific and technical works of M. H. Fayol) hereafter referred to as La Notice. To our knowledge, this text has never been translated into English. (N.B.: The quotations from La Notice are our own translation.) Coubrough's bibliography cited La Notice with an incomplete reference, and Storrs did not even mention it. Fayol submitted La Notice, a detailed account of his scientific endeavors, as part of his application for membership in the Academy of Sciences (Peaucelle, 2003). La Notice presents the curriculum of Fayol by himself. The document includes three parts: First, it lists the titles and functions he had during his career, the awards he received and the scientific and technical publications he achieved. Second, Fayol develops his own view about his scientific contribution ("Etats de service"). And third, he develops in a more detailed some scientific works and results together with their reception within the scientific and professional communities. This text has been overlooked and deserves careful attention as Fayol explicitly connected the example of his company and the administrative principles of the GIA. One century after the publication of the GIA, this forgotten text, in addition to historical data, justifies revisiting and reappraising Fayol's contribution.

\section{Rereading Fayol's GIA: historical data, discourse analysis, and theoretical discussion}


To read Fayol's main treatise through the new lenses provided by La Notice, we combine three different research methodologies: historical data, discourse analysis and theoretical discussion. Together, these methodologies provide a bundle of convergent evidence that supports a new interpretation of GIA.

Historical data. An accurate account of Fayol's scientific achievements is a necessary ground for a new scholarly reading of GIA. Today we can draw on robust historical material about Fayol's endeavors as a manager to promote scientific research, to attract scholars and to develop innovative structures and processes for the administration of science driven industries (Bertilorenzi et al., 2016; Segrestin, 2016)i. These structures and processes were a central pillar of its practice and a major cause of its enduring legitimacy at the head of his company. This observation is reinforced by Fayol's testimony in La Notice. It supports the idea that Fayol's scientific innovations have inspired GIA principles.

Discourse analysis. If GIA's claim is to uncover general principles of a new science, it presents no systematic discussion of existing literature excepting a long discussion of Frederick Winslow Taylor' classic text. Yet, we find in La Notice new intertextual correspondences (Fairclough, 1992), that challenge our understanding of Fayol. La Notice invites to relate the theoretical concepts of GIA to Fayol's actions and thoughts about scientific research. It invites to see Fayol's administrative theory as the impact of science on business. We analyze the original French text of GIA looking for notions, propositions and statements that exemplified Fayol's aim to integrate science and business. We find that these notions were concentrated in the section on "Prévoyance" of GIA and constituted the theoretical backbone of the whole treatise. To express these ideas, Fayol introduced a distinctive and sophisticated vocabulary that is completely different from business and economic texts of his time. These unusual notions shape the message of all other sections of GIA, where Fayol develops subsequent details of his administrative theory.

This finding raises two new issues: why did Fayol use special linguistic resources to formulate his administrative science? Where did they come from? We consult a French dictionary and thesaurus: Le Trésor de la langue française (hereafter TLF), the French equivalent of the Oxford English Dictionary (Pierrel, 2006). This reference details the etymology and history of a word, as well as its accepted meanings and usage in different semantic contexts over time. The discourse analysis shows that Fayol drew extensively from the language of philosophy and political theory, and other fields not typically associated with business and economics then or now.

We also analyze Fayol's archives to capture his own readings and references. Even, if we still lack a complete picture, we find some evidence about his interest in political theory in a notebook (Fayol, 1924). Fayol noted his personal reflections and comments about the recently published book of Lord James Bryce on modern democracies (Bryce, 1922), that he studied carefully. Fayol was clearly aware that his central concepts came from political philosophy, but more than that, he was convinced that his theory of administration was a contribution to modern political thinking: GIA clearly targets a new vision and administration of the State.

Theoretical discussion. These findings lead us to our central proposition: the core ambition of Fayol's administrative theory was to explain the construction of authority, cohesion and solidarity in social bodies (the company, the state) that have to cope with unpredictable futures implied by science and business. However, in the same period, other authors introduced new theories of management. Among them, the economist Franck Knight and the sociologist Max Weber made influential contributions. To complete our analysis of Fayol, we thus compare Fayol's administrative theory to these two landmark approaches in order to discuss Fayol's originality.

\section{Outline of the article}


The following sections establish and discuss these different findings. First, we introduce historical documentation concerning Fayol's scientific practice to show that for Fayol, the advancement of science and technology required a new kind of organization and management. In the second part, we interpret Fayol's GIA according to this understanding. Insights from Fayol's scientific achievements illuminate overlooked, but key, theoretical propositions. We show that the GIA makes scientific activity and research a central task of management. The main purpose of management is specified by the universalistic notion of perfectionnement. We show that Fayol considered that science change the predictability of business: as a company can provoke unpredictable future with its own scientific breakthroughs, new administrative principles to prepare the organization. Finally, we show in the third part, that Fayol's work foreshadows several issues addressed today in the literature on innovation management. We also discuss the more fundamental contribution of Fayol. By comparing Fayol's views on management to those of: i) Frank Knight, an influential economist that introduced radical uncertainty and management in economic theory; and ii) Max Weber's theory of bureaucracy, we establish that Fayol built a conceptual alternative to economic theory and to bureaucracy as a basis for administrative and organization science.

\section{THE SCIENTIFIC SIDE OF FAYOL'S CAREER: HISTORICAL EVIDENCE AND DATA}

In his lifetime, Fayol was recognized for his leadership in industry, science, and education. $\mathrm{He}$ was particularly committed to scientific and technical research (de Fréminvillé, 1927, Peaucelle 2003). Fayol maintained that scientific research had become a key factor of economic and industrial development. This idea had been spreading throughout the $19^{\text {th }}$ century; and in the early 20th century scholars called for the development of industry-based research such as corporate laboratories. The same year as the publication of the GIA, Mees (1916) presented a seminal study in Science on the organization of industrial scientific research. He claimed that research labs were "a final insurance against eventual loss of the control of its industry by any concern" (Mees, 1916: 764). Fayol not only recognized the role of research, he also considered that it was the role of management to engage the enterprise productively with science and research. This understanding came with Fayol's proven leadership in this regard, as documented in La Notice. The text provides numerous scholarly references confirming the quantity and quality of Fayol's scientific contributions. Subsequent research, particularly in natural science journals, further confirms these achievements (Beaudoin, 2003; Cahn, 2005; Chevenard, 1933, 1951; Guillaume 1920 ). In this section, we re-establish the record of Fayol's largely forgotten scientific works and outline their managerial significance.

\section{Science and Productivity Management in Mining and Geology}

Fayol began his career as a manager and researcher at the Commentry mine in 1866 . Commentry, in central France, was known for its coalfields, foundries, and forges. The Commentry mine was run by the Societé de Fourchambault, Commentry and Decazeville. Fayol spent his entire career with this company. One of his first challenges was to resolve a crisis: the mine, known for the richness of its fossils, experienced frequent fires. Seeking safer and more productive mining techniques, Fayol turned to geology, which he had studied extensively. He instructed workers to document and recover all fossil traces and prints they discovered. Geologists recognized Fayol's assistance. In 1914, one scholar reported:

$[W]$ e have benefited from such valuable support in France, in Commentry for example, where engineers and workers under M. Fayol's management have zealously outdone themselves collecting prints that provided the most interesting information, not only on the flora, but also on the entomological fauna of the end of the coal era (Fayol, 1918: 13). 
The idea of contributing to natural science while pursuing industrial productivity, two seemingly contradictory objectives, led Fayol to become a pioneer in geology. He subsequently developed his theory of river deltas. Previously, scientists had believed that coal ore resulted from the vertical accumulation of several layers of sediments. Drawing on field data from the mining activities, Fayol hypothesized that sediments were transported by water flows to a basin, where they accumulated according to the structures of a river delta. This theory changed the rationale and methods for efficient ore exploration and discovery. It also ensured the Commentry mine's prosperity: "Never was coal-bearing land excavated, analyzed and described in such depth. The theory of river deltas derives from it. Thanks to these scientific studies, Commentry's [mine] was fully and rationally exploited" (Fayol, 1918: 11).

\section{Scientific Ventures: Charles-Edouard Guillaume's Nobel-winning metallurgy}

When he was appointed General Manager of the Societé de Fourchambault, Commentry et Decazeville in 1888, Fayol became interested in the properties of the nickel steels produced at the company's factory at Imphy. Charles-Edouard Guillaume (1861-1938), a physicist at the International Weights and Measures Bureau (BIPM), noticed that certain steels from this factory presented surprisingly low thermal expansion rates. At that time, only rare and costly metals like platinum presented sufficiently low rates to build the prototypes that served as international standards for the meter. These special alloys from Imphy presented a potential alternative to platinum. Guillaume wanted to investigate their properties, but he lacked the funds and samples to do so. Beginning in 1896, Fayol provided Guillaume with all the necessary support. This collaboration continued for more than two decades, during which Fayol had hundreds of alloys delivered from Imphy to Guillaume (Fayol, 1918: 16; Guillaume 1920). The scientific yield in findings was as exceptional as the physical yield in product. Guillaume confirmed the existence of non-expanding nickel alloys, like Invar and Elinvar, with virtually unlimited applications in new industries and the potential for very high demand in the production of scientific instruments, high-precision watches, and wire-glass sealings. Cahn (2005) studied the fruitfulness of Guillaume's discoveries. In business terms, Invar alloys significantly contributed to the company's profitability. During the two decades following the discovery of Invar, special alloys represented only $1 \%$ of production measured in tons, but they generated more than two thirds of the profits (Lambret and Saindrenan, 1996).

What was Fayol's attitude when Guillaume approached him? Clearly there was no guarantee of success. Fayol gave Guillaume moral and financial backing because he sought continuing increases in the technical competency of his workshops and laboratories, which, as a good administrator by his own definition, he and the whole organization would capitalize on:

These results were only obtained as a result of the growing importance which the Commentry-Fourchambault et Decazeville company, under M. Fayol's administration and M. Pielin's [head of Imply's factory] management, gave to the scientific studies carried out by its engineers (Fayol, 1918: 18).

Fayol also agreed to share this industrial venture with Guillaume's institution, which was better equipped for the patient exploration of basic metallurgic phenomena. Guillaume finally explained the surprising properties of Invar and won his Nobel Prize in 1920. Their collaboration is a clear example of network-based knowledge production.

Fayol expected research not only to optimize existing processes but also to lead to new products and markets. Administering the synergies between basic research in metallurgy and its industrial applications became a major, but intangible, capability. In 1911, Fayol systematized this approach by asking Chevenard to build an innovative laboratory for the company.

The Imphy Laboratory: "a Large-Scale Programme" for science and innovative products 
In 1911, Fayol began creating a new laboratory that exemplified his vision of integrated scientific and industrial research. He entrusted this mission to a young engineer, Pierre Chevenard (1888-1960), who gave the laboratory an unprecedented capacity for metallurgical exploration (Chevenard, 1933, 1951). Chevenard (1951) later confirmed that Fayol articulated "a large-scale program" [un programme de grande envergure] that was completely original. Combining basic and applied science, the laboratory became a new experimental site for a new kind of worker: the "factory researcher who, through daily contact with the manufacturing processes, is surely the best placed to find the right balance" (Chevenard, 1951: 418).

Chevenard designed highly sensitive measurement devices that ensured scientific accuracy while being easy to operate and able to withstand constant use. This precision and speed allowed for accelerated trials, so lab workers could venture into unexplored areas without losing too much time. The research scope covered all stages, from alloy creation to small-scale and ultimately mass production. Reliable validation in the early stages of manufacturing ensured a smooth, rapid transition to industrial production. Later on, Mees (1916) distinguished three types of laboratories:

1. Works laboratories exerting analytical control over materials and processes;

2. Industrial laboratories working on improvements in product and in processes, tending to lessen cost of production and to introduce new products to the market;

3. Laboratories working on pure theory and on the fundamental sciences associated with industry (Mees, 1916: 765).

Fayol asked Chevenard to combine all three functions in the same structure. The Imphy laboratory can therefore be considered an innovative scientific laboratory (Le Masson and Weil, 2016), designed to simultaneously make basic scientific advancements and industrial improvements, and to optimize the creative association between free exploration and industrial efficiency (March, 1991). By 1918, Fayol had gained the admiration of recognized experts, including Henry Le Chatelier, a noted scholar and admirer of Frederick Taylor (Fayol, 1918: 18).

Against all expectations, classical readings of the GIA do not connect Fayol's theoretical writings to his scientific records: the administrative principles are assumed not to be inspired by this part of the author's experience. The alternative hypothesis has guided our research: we follow Fayol who stated that these scientific ventures and achievements were the result of his administrative theory to reevaluate Fayol's contribution to management thought (Alvesson and Sandberg, 2011).

THE INTEGRATATION OF SCIENCE AND BUSINESS: A CORE ISSUE IN THE GIA GIA does not cite any of the scientific works heralded by Fayol in La Notice, such as Invar, the theory of deltas, or the Imphy laboratory. However, the link between Fayol's administrative theory and his scientific initiatives appears in key terms that figure prominently in both works: recherche [research], laboratoire [laboratory], État-major [staff] and perfectionnement [advancement]. In this section, we first analyze the notion of perfectionnement, wich appears at the central purpose of the management. We then show that, in Fayol's view, this purpose calls both for laboratories and new staff, but also for original administrative tools, such as the notion of programme. We finally explain how these original concepts and their meanings have been partially lost in the translations of the GIA.

Perfectionnement as the main purpose of Management: the legacy of political philosophy Perfectionnement, whose traditional translation by "improvement" may have been misleading, is especially significant, for it described the main purpose of the new administrative science: 
One of the most important [duties] is the search for improvements [perfectionnements]. It is well known that a business which does not go forward is soon behind its competitors, and that consequently progress in every sphere must be pursued unremittingly (Fayol, 1949: 64).

By defining perfectionnement as the central purpose of his management theory, Fayol seeks universality for his science and is faithful to his idea that "management principles aim at the success of associations of individuals and at the satisfaction of economic interests" (Fayol, 1949: 42). Perfectionnement encompasses non-economic or social goals as well as economic goals. When Fayol published GIA, the term had a rich philosophical legacy. Perfectionnement was a key term in the French Enlightenment and political philosophy. French academic institutions had administrative boards called "Conseil de perfectionnement" to indicate their higher and nobler ambitions, while business companies never used the term. The concept of human perfectibility appeared in Rousseau (1755). It held a central place in Condorcet (1795), who associated it with both the perfectibility of human morality and with the infinite advance of the Arts and Sciences. Chaptal (1800) associated perfectionnement with the industrial arts in his Essai sur le perfectionnement des arts chimiques en France (Essay on the advancement of chemical arts in France). Comte (1907) defined perfectionnement as the central purpose of his "positive" philosophy: "le positivisme assigne pour but continu à notre existence, personnelle et sociale, le perfectionnement universel..." (Comte, 1907: 113) ["Positive philosophy designates universal perfectionnement as the enduring aim of our personal and social existence"- our translation]. When Fayol instructed managers that "[perfectionnement] in every sphere must be pursued unremittingly" (Fayol, 1949: 64), he echoed Condorcet's proposition that "the perfectibility of man is truly indefinite; and that the progress of this perfectibility from now on, which works independent of any power that might wish to halt it, has no other limits than the duration of the globe upon which nature has cast us"[our translation] (Condorcet, 1795: 9).

Perfectionnement requires managers to value all forms and domains of progress equally. Management theory thus applies to all spheres of activity. It organizes not only the collaboration between science and business but also between the social and the economic spheres and between humanistic and material values. Fayol refers to the organization's personnel as the corps social (Fayol, 1916: 4). Storrs translated this as "corporate body" (Fayol, 1949: 20), but the French expression comes from political philosophy and designates society as a whole (TLF, 2014). Fayol drew an analogy between company personnel and the citizens of a nation or state: the company's management must work to "compose the corporate body" [corps social] (Fayol, 1949: 54). Fayol thus constructed his administrative theory with references far broader than the technical terms typically associated with business practice. His manager was, and is, much more than a businessman in the ordinary sense and transcends the traditional opposition between technical and social approaches in management thought (Child, 1969).

The English term "improvements," used by both translators of Fayol, bears no trace of this rich philosophical legacy. Perhaps Fayol should have introduced perfectionnement as a new element of administration. Urwick (1937) did propose what he called the "investigation principle." But perfectionnement is not an element or method: it is management's raison d'être. With such high moral and scientific aims, Fayol gives management theory a universal ambition, the scope of which resembles other forms of enlightened government. This explains why Fayol speaks of the State as a "national enterprise" (Fayol, 1949: 52): he thought that state government could benefit from the new administrative science.

\section{Organizing for perfectionnement}


But perfectionnement is highly demanding and encompasses both breakthrough innovations and continuous improvement. It requires appropriate methods and determination. Fayol states that "managers absorbed by current work and by weighty questions calling for immediate settlement usually do not have the requisite time to devote themselves to developing research." Several conditions must be met in order to "to keep the business abreast of perfectionnement" (Fayol, 1949: 64): in addition to the necessary financial backing, the organization of research in dedicated laboratories and the introduction of special staff are required.

The Laboratory: a key element of general management. In the Appendix to the GIA, Fayol emphasized the importance of the research function in modern business: "Industry would acquire both honor and profit by providing the funds required to improve laboratories and relieve research workers from the material cares of existence" (Fayol, 1930: 81). This statement explains the vital role assigned to the laboratory in the GIA. It is much more than a technical department or function. It is a core resource for the executive management and the organization. Fayol explicitly described the laboratory as a special organ of "the chief executive" and particularly of its special staff [l' État-major] (Fayol, 1949: 62-63).

L'État-major: staffing for innovation and breakthroughs. Fayol's leadership in industrial innovation rests on an unusually complex staff organization that he calls l'État-major. He acknowledges the military origins of the term, which describes the group of officers that assist the high commander. But Fayol's staff does more than monitor and support ordinary operations. Compared to the standard theory of bureaucracy (Mintzberg, 1979), the staff has a new function: it prepares for the future by constantly searching for perfectionnements to be introduced "into every sphere" (Fayol, 1949: 64). "It is by close and unbroken collaboration of executives with staff that the major part of the countless perfectionnements filling the pages of technical publications is effected" (Fayol, 1949: 65).

Interestingly, the staff goes beyond the organization's boundary, as the company taps "specialist consultants" who are "giving only a part of their time to the company" (Fayol, 1949: 65). The research conducted internally is also expected to contribute to knowledge worthy of scholarly publication. This requirement echoes Fayol's research experience directly, it was the standard to which he held not only himself, but also his organization.

\section{Beyond planning: Fayol's theory of programmes in the "unknown"}

If perfectionnement is central to the executive function, then the usual Fayolian principlesplanning, organizing, commanding, coordinating, and controlling - are not mundane activities after all. In this section, we probe further into Fayol's theoretical innovations. We show how the concept of programme [program], together with the notions of prévoyance [foresight] and l'inconnu [the unknown], provide the administrative tools to operationalize perfectionnement. For Fayol, to manage is "to foresee and provide means examining the future and drawing up the programme of action" (Fayol, 1949: 6). The word programme, translated as "plan," comes from the fields of education and entertainment. It means the description of upcoming activities. But in the $19^{\text {th }}$ century, the term took on a political meaning, with references to the programme of a government or political party (TLF, 2014). A programme can be interpreted as a "plan" if it lists scheduled tasks, targets, and deadlines, such as a production or commercial plan in a business. But a programme can also describe a general statement, a manifesto, or the written constitution of an organization or a political party. Fayol clearly referred to the second meaning when he used the notions of programme d'action [action plan] or programme général d'action [general action plan]. Thus, he gave a political dimension to the general manager by using the concept of programme, which expresses the widest range of authoritative action. But most importantly, the concept of programme expands the notion of planning and allows managing in the context of unpredictable futures. This is particularly appropriate alongside the notion of prévoyance. 
Prévoyance: preparing for future unpredictability. Scholars have extensively discussed the translation of prévoyance (e.g., Parker and Ritson, 2005; Brodie 1962). Fayol's definition goes far beyond the conventional translation of "planning." In Fayol's time, prévoyance referred to the act of organizing mutual aid, insurance, and social solidarity for unforeseen emergencies and disasters. It was thus tied to the objective of social stability and the endurance of a society or social system. But Fayol extends prevoyance as the need to prepare for the future despite the inability to foresee it. Executives act according to their judgment about "future trends which depend partly on technical, commercial, financial and other conditions, all subject to change, whose importance and occurrence cannot be predetermined" (Fayol, 1949: 43). Contrary to the notion of "planning," Fayol based his prévoyance largely on a vision of the future that rejects predictability and admits "the unknown." Good prévoyance means organizing according to this unknown and preparing "the programme" to face it. Because the future is unpredictable, it is important not only to know "what is possible" but also "what is wanted" (Fayol, 1949: 43). Thus Fayol's prévoyance must be understood in relation to perfectionnement: to foster perfectionnement, the management must maintain the technical competence, the motivation to achieve the corporate objectives, and the ability to adapt the corps social [corporate body] to unforeseen circumstances.

A contingency theory of programmes: acknowledging the unknown. Fayol instructed that the programme be characterized by unity, continuity, flexibility, and accuracy. Most importantly, he specified different types of programmes according to a contingency factor: "the share of unknown [part d'inconnu] bearing on the fate of the concern" (Fayol, 1949: 45). In some unique, complex sentences that typify the sophisticated style he used to express complex new ideas, Fayol associated a certain kind of programme with surprise and adventure. These passages, which closely follow the letter and spirit of La Notice, introduce the notion of "l'inconnu" (the unknown) that implies an original typology of programmes.

Fayol gives no explicit definition of "l'inconnu". Actually, with the advancement of science, the layman of the $19^{\text {th }}$ century had a direct and common experience of "l'inconnu": countries, populations, animals, diseases, that were unknown were discovered almost every day. The more science progressed, the more it proves the existence of the unknown. Business men were more used to notions of "fortune", "chance" or "risk". Fayol avoids such language that recalls the life and gambles of the merchant. He introduces the notion of the "unknown" which is also different from "the uncertain" that became dominant in economics (this is discussed in more detail in the last section of the paper). He clearly states that the "share of unknown" [la part d'inconnu] determines how to act as a manager i.e. how to design appropriate programmes. According to the share of l'inconnu [the unknown], the programme can be a plan, a directive, or a venture:

- $\quad$ Programmes as plans: "Usually [i.e. when the share of unknown is small] it is possible to draw the line of proximate action fairly accurately" (Fayol, 1949:45). Fayol clearly refers to conventional business plans. He gives examples of such plans for a mine and a metallurgical plant. This type of plan should be prescribed by management and followed by the corps social, as closely as possible. But it will not sufficiently foster perfectionnement, scientific research, and technological breakthrough.

- $\quad$ Programmes as directives: If the share of unknown is significant, then the programme cannot be elaborated as a plan until further information is available. Fayol suggests using a directive. The French term directive has been translated by "indication," but it is more sophisticated and semantically complex than this English word. Fayol again took directive from political and the military tradition (TLF, 2014). The term refers to general instructions given by an institution or a high authority, which do not specify details but leave considerable discretion to the addressee. The term implies sufficiently strong authority not to say more. It invests high trust in a person or office and communicates this trust throughout the corps social. The directive corresponds to the mission that Fayol gave Chevenard when he appointed him head of the 
Imphy laboratory and asked him to link research and production (Chevenard, 1933): it gave Chevenard authority and conveyed what Fayol expected at one and the same time.

- Programmes as aventures: "When the share of the unknown occupies a relatively large place, there can be no precision in the plan [in French: programme], and the concern takes on the name of venture [in French: aventure]" (Fayol, 1949: 45). Fayol accepted this option as a concrete possibility and even saw it as a rational state of affairs. Conventional wisdom might see the future as full of opportunities. But in a highly unknown context, like scientific research, Fayol understood that opportunities would only appear thanks to active efforts of perfectionnement. Fayol undertook such ventures when he supported Guillaume, for example. They were intrinsic to scientific activity and required administrative principles adapted to the exploration of a completely unknown future.

Designing programmes: a creative act. Fayol's theory of programmes clearly goes beyond the case of a plan that can be deduced from straightforward predictions and goals. Elaborating the programme calls for a special type of rationality that Fayol compares to the architect's rationality (Fayol, 1949: 43). By comparing the manager with the architect- and not with the engineer- Fayol clearly outlines the creative aspects of the design of programmes. Building the programme can use existing models but must remain open to creative invention. The unknown requires both freedom of action and creative capability.

With the interrelated concepts of perfectionnement, prévoyance, programme and l'inconnu, Fayol established the basis of a new administrative theory and offered a contingent typology of programmes (plans, directives and ventures) according to the level of "the unknown.". Fayol himself recognized the pioneering nature of his concepts and thus acknowledged that his own practice was not sufficient to provide a complete theoretical understanding. He ended the section on programmes, one of the most creative of GIA, by stating that the "management theory [of programmes] has yet to be formulated" (Fayol, 1949: 45). However, his theory could reconcile the unprecedented and unpredictable future generated by the integration of science and business with the new level of responsibility invested in the chief executive position.

\section{The Limited Reception of Fayol's key concepts: the impact of Translation}

After World War II, Fayolian studies were led mainly by Anglo-Saxon authors who relied extensively on Coubrough and Storrs translations. As mentioned above, Fayol's novelty was all the more difficult to apprehend in the original even more than Fayol's concepts challenged translators.

Our re-rereading of key concepts in the GIA has been guided by historical data on Fayol's scientific achievements and by La Notice. As stated earlier, the conventional interpretations did not include these references. The pioneering nature of Fayol's contributions was overlooked, and his theory was interpreted conventionally, as adaptive planned action. Whereas Fayol introduced two unusual terms to the business world, prévoyance and programme, the translations collapsed them into the single, commonly used "planning." Perfectionnements was also diminished through its translation as "improvements." We have emphasized Fayol's statement that this process must make original contributions to science. In addition, as stated earlier, perfectionnement has a rich philosophical legacy and significance. It describes the ambitious march of science and industry towards new and greater discoveries, as well as social and moral advances. Translators also compromised Fayol's directive, which belongs to political vocabulary and highlights a legitimate authority's capacity to set purposes and delegate responsibility. They translated directive by banal expressions such as "general guide" (Fayol, 1930) or "simple general indication" (Fayol, 1949), while "directive" exists in English and as the same meaning than the French word: "an official or authoritative instruction" (Oxford on 
line English dictionary). Additionally, the connotations of authority were hidden: any organizational actor may provide guidelines or indications, but the directive can only come from one authority. Fayol used these original terms to convey a new understanding of organization and administration. This view made scientific research a top priority for both entities. In particular, he established a necessary middle ground between daring action in the face of the unknown and responsible action for ordinary business practice.

Finally, translators diluted the strength of Fayol's "unknown". Coubrough spoke of "unknown forces"; Storrs, of "unknown factors." Transforming the noun into an adjective literally takes the substance from the word and relates it to the idea of external forces weighing on an executive's and an organization's life. For Fayol, the "unknown" has profound significance because it concerns the aggregate and undefinable potential of all the perfectionnements pursued in scientific and social progress, as well as those directly bearing on the business. Perfectionnement, prévoyance, programme, and l'inconnu form a network of terms and ideas mapping a new range of executive and organizational action.

Now, what is the value of such reinterpreted legacy for today and tomorrow's management theory? We establish in the next section that Fayol's GIA foreshadowed the modern management of innovation and formed a theoretical basis for management independent of economics and of bureaucracy theory.

\section{DISCUSSION: FAYOL'S THEORETICAL LEGACY FOR THE FUTURE OF MANAGEMENT}

\section{Foreshadowing Contemporary Research on Innovation Management}

By making l'inconnu [the unknown] a central challenge of organization, Fayol introduced a centripetal force. He addressed the growing complexity of organizational forms that needed to coordinate "separate" functions and host emerging organic communities (Burns and Stalker, 1961). Compared to the early steps of innovation management, Fayol's staff, innovative laboratory, and programmes appear as precursors of sophisticated structures and functions that were later conceptualized as "ambidextrous organizations" (Damanpour, 1991, 1996; Tushman and O'Reilly, 1996). These organizations are able to strategically link activities associated with different, even conflicting, purposes and processes (Birkinshaw and Gupta, 2013). These structures also demonstrate an "absorptive capacity" to gain and apply new information coming from outside the company (Cohen and Levinthal, 1990; Lane, Koka and Pathak, 2006; Lewin, Massini and Peeters, 2011). In Fayol's theory, the level of "the unknown" is the contingency variable that induces the need to combine conflicting processes. It also transcends hierarchical levels, temporal horizons, and organizational boundaries, systematically (O'Connor, 2008). Fayol clearly stated the importance of tapping into resources originating from outside the company and of developing enduring networks of research, announcing "open innovation" far in advance (Chesbrough, 2003).

Creative leadership. By his example and theory, Fayol contributes to the emergence of a new kind of leader whose responsibility is to engage a collective endeavor into the unknown. The Fayolian leader is able to launch ventures, generate motivation, and develop the collective capability to face an unpredictable future productively. Fayol theorized a new type of authority that we call "creative" because, as previously noted, he held perfectionnement as its central purpose. He also activated teams of external experts and laboratories by elaborating bold but rational programmes. These concepts capture a creative function that engages and stimulates the whole organization. This function anticipates the concept of "transformational leaders" (Grant, 2012; Judge and Piccolo, 2004) that build on collective values and identities to motivate others to reach objectives (Bass, 1985 ; Kotter, 1990; Shamir, 1998; Shamir, House and Arthur, 1993). 
Innovation as creative design. Fayol conceived the raison d'etre of administration as the ability to renew a company's goals, competencies, and processes. This point of view was later conceptualized as the development of dynamic capabilities in organizations (Eisenhardt and Martin, 2000; Teece and Pisano, 1994). Moreover, Fayol's insistence on all types of perfectionnements as means to succeed industrially and scientifically is not so far from current research that explores the capacity of a company to foster disruptive or major innovations (Christensen, 1996; O'Connor and DeMartino, 2006; Van de Ven, Polley, Garud and Venkataraman, 1999; Van de Ven, 1986 ). Actually, by including bold explorations, scientific research, and ventures in his theory of programmes, as well as by introducing the concept of the "unknown," Fayol paved the way toward alternative models of rationality. These models appeared recently in studies of innovative projects where uncertainties are very high, parallel options have to be tried simultaneously, and previously unknown solutions may emerge during the project's course (Sommer and Loch 2004). Alternatives forms of rationality are also central for the study of creative forms of design that foster innovation both in strategy and organization (Hatchuel, 2001; Saravasthy and al. 2008; Hatchuel, Starkey, Tempest and Le Masson, 2010). These converging observations do not mean that Fayol envisioned the speed and scope of present technological changes, or that he conceptualized innovation management as research does today. But they do confirm that he aimed to comprehend all the managerial consequences entailed by integrating science and industry. And one of these major consequences was the fact that many important but unknown future possibilities would be discovered only if research and perfectionnement have strategic attention and centrality. With such a premise, Fayol's administrative principles were designed to foster innovative changes and solutions. And finally, within Fayol's perspective, the term "management of innovation" may seem pleonastic because his management science makes innovation one of its central goals.

\section{The essence of management science: a "creative/political" theory}

Fayol conceptualized management in a world where scientific research, together with all types of perfectionnements, called for new concepts of leadership and organization. Is this integration of science and business specific to Fayol? Recent work on the history of management (O'Connor, 2012) highlights the contribution of classical authors like Mary Parker Follett and Chester Barnard. These authors also found original ways of articulating this new, expansive field: Follett's creative "circular relations" and Barnard's "organic applied social science." But we find that Fayol remains the only one to have confronted the aventure of scientific research in his administrative theory. To meet this challenge, he needed theoretical and linguistic resources that he couldn't find in standard administrative and economical language of his time. We argue that Fayol aimed to build the foundations of a radically new management science without any reference to economics and to bureaucracy theory, which constituted the paradigmatic backgrounds for such theory. First, several years before the economist Frank Knight, Fayol distinguished the crucial function of top management and advanced an autonomous theory of administration independent of economic theory. Second, Fayol fully rejected the bureaucracy (Weber, 1922) that he observed in the State and in public authorities.

Management Theory without Economics: A Comparison of Fayol and Knight. Frank Knight is an influential economist that made management central to economic life: "[...] to find men capable of managing business efficiently and secure to them the positions of responsible control is perhaps the most important single problem of economic organization on the efficiency side" (Knight, 1921: 283). He also focused on how unexpected advances in science affected ongoing organizational action: "[...] the most fundamentally and irretrievably uncertain phases or factors are those who amount essentially to the increase of knowledge as such. This description evidently holds for the improvement of technological processes and the 
forms of business organization and for the discovery of new natural resources" (Knight, 1921: 318). But Fayol and Knight grounded their similar propositions in completely different theoretical sources, revealing Fayol's originality in a number of respects. Knight started from the premises of classic economic theory, particularly the concepts of perfect competition and rational man. While acknowledging radical uncertainty, he also contended that economic life transpires through and is sustained by management. Comparatively, Fayol made no reference in the GIA to economic science or its classical concepts such as market equilibrium and profit maximization. As we have shown, he systematically avoided economic concepts and opted for political references instead.

Uncertain vs. unknown future. Most importantly, Fayol and Knight have deeply different approaches to the future. For Knight, the primary purpose of knowledge production is to reduce radical uncertainty: "The fundamental principle underlying organized activity is therefore the reduction of the uncertainty in individual judgments and decisions...." (Knight, 1921: 203). But this position makes investments in research particularly difficult to justify. Knight thus falls back on an ad hoc argument presuming some level of information about the future:

Though we cannot describe a new invention in advance without making it, nor say what quantity and quality of new natural productive capacity will be developed and where, yet it is possible in a large degree to offset ignorance with knowledge and behave intelligently 'with regard to the future' (Knight, 1921: 318).

Fayol, instead, theorizes "the unknown," including the extreme case of an unpredictable future with a very large share of "unknown" resulting from external sources, such as competitors and government, and from internal sources, including managerial action itself. While scientific research is not the only source of the unknown, a leader can influence its course by seeking protection from it, or more audaciously, by endeavoring to induce an unknown that benefits the company. Unlike Knight, Fayol does not have to explain the lack of a calculable economic argument to justify his scientific mission. Simply put, if perfectionnement is the central purpose of management, it requires investing in the unknown; and the challenge becomes a managerial one. Even modest investments do not bear fruit unless they are undertaken by scientists who closely collaborate with the different parts of the company, especially the Etat-major and those who make up the executive body. Fayol sees radical uncertainty not as an obstacle to decisions that should be reduced but as the very basis of organization and the rationale of its scientific, economic, and social missions.

Management Science as a criticism of bureaucratic theory. Ultimately, our rereading of the GIA suggests that Fayol was seeking a theory of a new kind of rationality and authority. Fayol explicitly distanced himself from government bureaucracies, which he considered incapable of pursuing such objectives (Fayol, 1949: 74). Well-known parts of the GIA explain that the State should abandon its administrative routines and adopt Fayol's principles. The Weberian concept of the "rational-legal" model of authority appeared after Fayol's GIA (Weber, 1922). Yet Fayol's critiques of State administration target the features of authority in what Weber called later "a rational-legal model". In his famous definition of bureaucracy (Weber, 1978) insists not on "perfectionnement" or on "action programs" but on rules:

"The management of the office follows general rules, which are more or less stable, more or less exhaustive, and which can be learned. Knowledge of these rules represents a special technical learning which the officials possess. It involves jurisprudence, or administrative or business management" (Weber, 1978: 958).

In Fayol's theory, rules exist but they are renewed by "prévoyance", by "programmes "and by the impact of research and continuous "perfectionnement". Directives and ventures also empower others to establish new plans and rules. 
Finally, the construction of the "corps social" is in itself a way to adapt rules to new people and new competences. Instead, in Weber's Bureaucracy, rules cannot be personal or individualized: "The reduction of modern office management to rules is deeply embedded in its very nature. The theory of modern public administration, for instance, assumes that the authority to order certain matters by decree--which has been legally granted to public authorities--does not entitle the bureau to regulate the matter by commands given for each case, but only to regulate the matter abstractly" (Weber, 1978: 958)

In the bureaucratic model, the Fayolian Staff, (i.e. specialists and scholars commissioned to induce perfectionnement without ruling authority) are almost unthinkable. As would be the long collaboration between Fayol and Charles-Edouard Guillaume who never was a member of Fayol's Company. Fayol rejected in advance Weber's view that bureaucracy was the model of both the state and the company. He stated that the domination of legal and abstract rules induced lack of tenure and responsibility and finally the absence of prévoyance which he summarized in his famous formula: "the French nation is far seeing [in French: prévoyants]. Its government is not" (Fayol, 1949: 52).

\section{Management theory as a creative/political model of authority}

Departing from economic theory and from bureaucracy theory, Fayol emphasized the role of managerial authority but grounded its legitimacy in an administrative model specifically adapted to face the unknown. Facing the dynamics of science and its large share of the unknown, Fayol acknowledged that decision formulation and execution depend on the political functioning of the organization. Thus, the role of the manager is not only to engage the corporate body through creative ventures and to encourage all types of perfectionnements, but it is also to prepare the organization to face the unknown and to develop its capabilities. In this way, Fayol suggests a political model of decision: the manager's decisions must be "clear, distinct, precise" (Fayol 1949: 54) to be understood and to elicit action. But more importantly, they must be elaborated in light of "advice from several competent people" (Fayol, 1949: 73). The executive, for example, must act resolutely, but only after consulting with different offices whose expertise is key for decision-making. This authoritative/participative model of decision requires, as Fayol states, the adequate composition and the union of the corporate body. The quality of the articulation of and the competent execution of decisions rest upon the development of the corps social [corporate body]: this point shows the key role of prévoyance in the Fayolian system of management. Managers must perfect the corps social and develop its technical capabilities because it engages the new rational way to approach decision-making in a dynamic context. Again, prévoyance and perfectionnement are management's key responsibilities: they form the two pillars of a rational/creative organization as they enable scientific and economic advances, as well as the solidarity and stability of the corps social [corporate body].

To summarize, Fayol theorized what we call a creative/political kind of rationality and authority. Fayol conceived of management for the modern and science-driven enterprise, with astonishing power to produce innovation and prosperity. To model the authority behind or underlying this management, Fayol rejected the idea that the new administration science leads to technocracy or to the domination of economic rationality. He advocated creative decisions favoring research and innovation. But at the same time, he rejected a purely legal theory of this new authority. He knew that breakthroughs entail commitment, competence, and advice within and outside the corporate body. Not only does it require managers to pay the highest attention to scientific research, but also they must develop the political body of the organization itself to face the unknown productively. He thus combined two types of principles: those that foster the creative behavior of managers (perfectionnements, research), and those that favor careful 
political behavior with the utmost attention to the composition of the organization and to the union the corporate body.

\section{CONCLUSION}

We have presented a new interpretation of Fayol, who developed a theory of administration based on the idea that science could be exploited industrially and commercially in a particular collective entity, by a new political authority and according to a new rationality. He found no help in conventional business ideas, academic economics, or bureaucracy theory. He drew from the tradition of modern political philosophy, which gave a rich foundation of generalized political concepts and thus allowed the largest scope and variety of actions and missions. This tradition also allowed him to posit a universal purpose for administrative science, which aims not only to exploit natural and physical sciences for the company, but also for the social body and for society-at-large. Drawing from political philosophy, he explored a new kind of creative/political rationality, where the chief executive has a new type of authority, charged with composing and unifying a new social body with the greatest scientific, business, and social ambitions

Our research has some limitations and calls for further investigations. From a historical point of view, we recognize the need for a comprehensive inquiry into Fayol's readings and philosophical sources. Research could also be extended to the study of the cultural background of other key figures who collaborated with Fayol. Finally, considering the evidence brought to bear in this article and the development of the field of innovation management, we believe that a completely new translation of Fayol's masterpiece is in order.

From a theoretical point of view, we invite further research into the concept of a creativepolitical theory and the extent to which it is relevant for other major authors such as Chester Barnard, Mary Parker Follett, and Peter Drucker. To conclude, we hold that our new interpretation of Fayol contributes to management and organization studies as a whole. The field has often been conceived of as a hybrid, made up of the economic, social, and quantitative sciences. Fayol points to another theoretical basis: a tradition of political philosophy, recast for collective enterprise pursuing creative, scientific, economic, and societal advancements. Because of the stakes involved in contemporary responsible innovation and sustainable value creation, we find this century-old theory eminently worthy of exploration and application. 


\section{REFERENCES}

Alvesson, M., and Sandberg, J. (2011). 'Generating research questions through problematization'. American Management review, 36 (2):247-71.

Bass, B. M. (1985). Leadership and performance beyond expectations. New York: Free Press.

Beaudoin, B. (2003). 'Henri Fayol, géologue perspicace et novateur?'. In Peaucelle, J.-L. (Ed.), Henri Fayol, Inventeur des outils de gestion. Paris: Economica, 47-67.

Bertilorenzi, M., Passaqui, J.-P., \& Garçon, A.-F. o. (Eds.). (2016). Entre technique et Gestion. Une histoire des «ingénieurs civils des mines » (XIXe-XXe siècles). Paris: Presses des Mines.

Birkinshaw, J., and Gupta, K. (2013). 'Clarifying the distinctive contribution of ambidexterity to the field of organization studies'. Academy of Management Perspectives, 27 (4):287-98.

Breeze, J. D., and Bedeian, A. G. (1988). The administrative writings of Henri Fayol: A bibliographic investigation. Vance Bibliographies.

Brodie, M. B. (1962). 'Henir Fayol: administration industrielle et générale - a re-interpretation'. Public Administration, 40 (3):311-17.

Bryce, J. (1924). Les démocraties modernes. Paris Payot.

Burns, T. E., and Stalker, G. M. (1961). The management of innovation. University of Illinois at UrbanaChampaign's Academy for Entrepreneurial Leadership Historical Research Reference in Entrepreneurship.

Cahn, R. W. (2005). 'An unusual Nobel prize'. Notes and Records of the Royal Society, 59 (2):145-53.

Carroll, S. J., and Gillen, D. I. (1987). 'Are the classical management functions useful in describing managerial work?'. Academy of Management Review, 12 (1):38-51.

Chambers, P. (1974). 'Europe's greatest management pioneer'. International management, 29:48-51.

Chaptal, J.-A. (1800). Essai sur le perfectionnement des arts chimiques en France. Paris: Deterville Librairie.

Chesbrough, H. W. (2003). 'The Era of Open Innovation'. MIT Sloan Management Review, 44 (3): $35-$ 41.

Chevenard, P. (1933). 'L'installation et l'organisation d'un laboratoire sidérurgique moderne'. Mémoires de la société des ingénieurs civils de France, septembre- octobre:3-52. (1951). 'La recherche scientifique dans l'industrie française. Réflexions et souvenirs'. Mémoires de la société des ingénieurs civils de France, Janvier-Avril.

Child, J. (1969). British management thought : a critical analysis. London: Allen and Unwin.

Christensen, C. M. (1996). 'Customer power, strategic investment and the failure of leading firms'. Strategic Management Journal, 17:197-218.

Cohen, W. M., and Levinthal, D. A. (1990). 'Absorptive Capacity: A New Perspective on Learning and Innovation'. Administrative Science Quaterly, 35: 128-52.

Cohen, Y. (2003). 'Fayol, un instituteur de l'ordre industriel'. Entreprises et Histoire, 34 (3):29-67.

Comte, A. (1907). Discours sur l'ensemble du positivisme. Paris: Société positivisite internationale.

Condorcet, J.-A.-N. C. (1795). Outlines of an historical view of the progress of the human mind [Esquisse d'un tableau historique des progrès de l'esprit humain]. Online Library of liberty. New-York: Lang and Ustick.

Damanpour, F. (1991). 'Organizational Innovation: A Meta-Analysis of Effects of Determinants and Moderators '. The Academy of Management Journal, 34 (3):555-90.

de Fréminvillé, C. (1927). 'Henri Fayol: a great engineer, a great scientist, and a great management leader'. Bulletin of the Taylor Society, 12:303-6.

Eisenhardt, K. M., and Martin, J. A. (2000). 'Dynamic Capabilities: What are They?'. Strategic Management Journal, 21 (10/11):1105-21.

Fairclough, N. (1992). 'Discourse and text: Linguistic and intertextual analysis within discourse analysis'. Discourse and Society, 3 (2):193-217.

Fayol, H. (1918). Notice sur les travaux scientifiques et techniques de M. Henri fayol. Paris: GauthierVillars et Cie Editeurs. Available at the website of the French national library: http://gallica.bnf.fr/ark:/12148/bpt6k904289.r=notice+fayol.langFR.

Fayol, H. (1924). Personal manuscript notebook. Fonds Henri Fayol, HF5 "Diverses études d'Henri Fayol", Archives d'histoire contemporaine, Centre d'histoire de la Fondation nationale des Sciences Politiques, Paris. 
Fayol, H. (1930). Industrial and General Administration London: Sir Isaac Pitman and Sons. (1949). General and Industrial Management. London: Sir Isaac Pitman and Sons.

Fells, M. J. (2000). 'Fayol stands the test of time'. Journal of Management History, 6 (2000):345-60.

Grant, A. M. (2012). 'Leading with Meaning: Beneficiary Contact, Prosocial Impact, and the Performance Effects of Transformational Leadership'. Academy of Management Journal, 55 (2):458-76.

Gray, B. (1989). Collaborating, Finding common ground for multiparty problems. Jossey-Bass.

Guillaume, C.-E. (1920). Invar and Elinvar, Nobel Lecture. The Nobel Foundation.

Gulick, L. (1937). 'Notes on the theory of organization'. In Gulick, L., and Urwick, L. (Eds.), Papers on the Science of Administration. New-York: Institute of Public Administration, 1-46.

Gulick, L., and Urwick, L. ( 1937). Papers on the Science of Administration. New York, NY: Institute of Public Administration.

Hatchuel, A. (2001). 'Towards Design Theory and expandable rationality : the unfinished program of Herbert Simon'. Journal of Management and Governance, 5 (3-4): 260-73.

Hatchuel, A., Starkey, K., Tempest, S., and Le Masson, P. (2010). 'Strategy as innovative design: An emerging perspective'. Advances in Strategic Management, 27:3-28.

Judge, T. A., and Piccolo, R. F. (2004). 'Transformational and Transactional Leadership: A MetaAnalytic Test of Their Relative Validity'. Journal of Applied Psychology, 89 (5):755-68.

Knight, F. H. (1921). Risk, Uncertainty, and Profit. New York: Sentry Press.

Kotter, J. P. (1990). A force for change: How leadership differs from management. New-York: Free Press.

Lambret, E., and Saindrenan, G. (1996). 'The discovery of Invar and the metallurgical works of CharlesEdouard Guillaume'. In Wittenauer, J. (Ed.), The invar effect: a centennial symposium. Warrendale, PA: The Minerals, Metals and Materials Society, 39-47.

Lamond, D. (2004). 'A matter of style: reconciling Henri and Henry'. Management Decision, 42 (2):33056.

Lane, P. J., Koka, B. R., and Pathak, S. (2006). 'The reification of absorptive capacity: a critical review and rejuvenation of the construct'. Academy of Management Review, 31 (4):833-63.

Le Masson P., and Weil B. (2016). 'Fayol, Guillaume, Chevenard - la science, l'industrie et l'exploration de l'inconnu : logique et gouvernance d'une recherche conceptive'. Entreprises et histoire, 2 (83): 79-107.

Lewin, A. Y., Massini, S., and Peeters, C. (2011). 'Microfoundations of internal and external absorptive capacity routines'. Organization Science, 22 (1):81-98.

March, J. G. (1991). 'Exploration and exploitation in organizationnal learning'. Organization Science, 2 (1): $71-88$

Mees, C. E. K. (1916). 'The Organization of Industrial Scientific Research'. Science, 43 (1118):763-73.

Mintzberg, H. (1975). 'The manager's job: folklore and fact'. Harvard Business Review, 53 (July-August 1975):49-61.

Mintzberg, H. (1979). The structuring of Organizations : a synthesis of the research. Prentice-Hall.

O'Connor, E. (2012). Creating New Knowledge in Management: Appropriating the Field's Lost Foundations. Stanford University Press.

O'Connor, G. C. (2008). 'Major Innovation as a Dynamic Capability: A Systems Approach*'. Journal of Product Innovation Management, 25 (4):313-30.

O'Connor, G. C., and DeMartino, R. (2006). 'Organizing for Radical Innovation: An Exploratory Study of the Structural Aspect of RI Management Systems in Large Established Firms'. Journal of Product Innovation Management, 23 (6):475-97.

Parker, L. D., and Ritson, P. A. (2005). 'Revisiting Fayol: Anticipating Contemporary Management'. British journal of management, 16 (3):175-94.

Peaucelle, J.-L. (2003). 'Fayol méconnu et toujours original'. Entreprises et Histoire, 34 (3):5-7.

Peaucelle, J. L. (2003). Henri Fayol: inventeur des outils de gestion: textes originaux et recherches actuelles. Economica.

Peaucelle, J.-L., and Guthrie, C. (2015). Henri Fayol, the manager. Studies in Business History. London: Pickering \& Chatto.

Pierrel, J.-M. (2006). 'Le Trésor de la Langue Française Informatisé: un dictionnaire de référence accessible à tous'. AMOPA (174):25-28. 
Pryor, M. G., and Taneja, S. (2010). 'Henri Fayol, practitioner and theoretician-revered and reviled'. Journal of Management History, 16 (4):489-503.

Reid, D. (1995). 'Fayol: from experience to theory'. Journal of Management History (Archive), 1 (3):2136.

(1995). 'Reading Fayol with 3D glasses'. Journal of Management History (Archive), 1 (3):6371.

Rousseau, J.-J. (1755). Discours sur l'origine et les fondements de l'inégalité parmi les hommes. Amsterdam: Marc Michel Rey.

Sarasvathy, S. D., Dew, N., Read, S., and Wiltbank, R. (2008). 'Designing Organizations that Design Environments: Lessons from Entrepreneurial Expertise'. Organization Studies (01708406), 29 (3):331-50.

Sasaki, T. (1995). 'Henri Fayol's family relationships'. Journal of Management History (Archive), 1 (3):13-20

Segrestin, B. (Ed.). (2016). Le tournant fayolien [special issue], Entreprises et Histoire, 83(2).

Shamir, B., House, R. J., and Arthur, M. B. (1993). 'The motivational effects of charismatic leadership: A selfconcept based theory', Organization Science, 4 (577-594).

Shamir, B., Zakay, E., Breinin, E., and Popper, M. (1998). 'Correlates of charismatic leader behavior in military units: Subordinates' attitudes, unit characteristics, and superiors' appraisals of leader performance'. Academy of Management Journal, 41:387-409.

Simon, H. A. (1946). 'The proverbs of administration'. Public Administration Review, 6 (1):53-67.

Sommer, S. C., and Loch, C. H. (2004). 'Selectionism and learning in projects with complexity and unforeseeable uncertainty'. Management Science, 50 (10):1334-47.

Teece, D. J., and Pisano, G. P. (1994). 'The Dynamic Capabilities of Firms : an Introduction'. Industrial and Corporate Change, 3 (3):537-56.

TLF. (2014). Trésor de la Langue Francaise [French Language Treasure]. Available at: http://www.atilf.fr.

Tushman, M. L., and O'Reilly III, C. A. (1996). 'Ambidextrous organizations: managing evolutionary and revolutionary change'. California Management Review, 38 (4):8-30.

Urwick, L. (1937). 'The function of administration with special reference to the work of Henri Fayol'. In Gulick, L., and Urwick, L. (Eds.), Papers on the Science of Administration. New York, 11530 .

. (1949). 'Foreword'. In Fayol, H. (Ed.), General and Industrial Management. London: Pitman.

Van de Ven, A., Polley, D. E., Garud, R., and Venkataraman, S. (1999). The Innovation Journey. NewYork, Oxford: Oxford University Press.

Van de Ven, A. H. (1986). 'Central Problems in the Management of Innovation'. Management Science, 32 (5):590-607.

Weber, M. (1922). Wirtschaft und Gesellschaft [Economy and Society]. Tübingen: J. C. B. Mohr (Paul Siebeck).

Weber, M. (1978). Economy and Society, Eds. Guenther Roth and Claus Wittich. University California Press.

Wren, D. A. (1992). 'The nature of managerial work: A comparison of Real Managers and traditional management'. Journal of Managerial Issues, 4:17-30.

Wren, D. A. (1995). 'Henri Fayol: learning from experience'. Journal of Management History (Archive), $1(3): 5-12$.

(2001). 'Henri Fayol as strategist: a nineteenth century corporate turnaround'. Management Decision, 39 (6):475-87.

. (2003). 'The influence of Henri Fayol on management theory and education in North America'. Entreprises et Histoire (3):98-107.

Wren, D. A., Bedeian, A. G., and Breeze, J. D. (2002). 'The foundations of Henri Fayol's administrative theory'. Management Decision, 40 (9):906-18.

Yoo, J. W., Lemak, D. J., and Choi, Y. (2006). 'Principles of management and competitive strategies: using Fayol to implement Porter'. Journal of Management History, 12 (4):352-68. 
i Still recently, Ecole des Mines de Saint Etienne, where Fayol has been trained as an engineer, organized a conference where the latest works on Fayol were presented for the centennial anniversary of GIA (Bertilorenzi et al., 2016). Similarly, a special issue of Entreprises et Histoire on the "Tournant Fayolien" (the Fayolian turning point) examined Fayol's theory in the context of the science-driven industry that flourished in Fayol's times (Segrestin, 2016). 